\title{
Analysis on the Housing Bubble in China
}

\author{
YuanYan Jiang
}

\author{
Hangzhou Foreign Language School,310023, China \\ *Corresponding author. Email: jiangyuanyan0307@hotmail.com
}

\begin{abstract}
With the market opening and development of Chinese economy, real estate is one of the biggest form of investment in China. Due to the continuation of purchasing real estate, China housing prices soars rapidly in main cities like Beijing, Shanghai, Shenzhen and etc, with housing price-to-income ratio becoming very exaggerated. Taking warning from past financial distortions happened in other countries like subprime crisis, some people foresee a formation of bubble in China's increasingly expanding housing market. Homeownership advantage, saving traditions, stable investment, undeveloped financial market, debt, loosening of government policy are all potential causes of the existence of housing bubble.
\end{abstract}

Keywords: Real Estate, Housing Market, Housing Bubble, Investment, Debt, China

\section{INTRODUCTION}

Real estate is one type of tangible properties made up of land and anything on it, including buildings and other natural resources. It has three essential characteristics: residential, commercial, and industrial, which, to some extent, covers nearly all aspects of human usage of their property [1]. In today's China, real estate is one of the key parts of the Chinese economy.

Due to the gradual market opening, the government policy of the housing sector including both housing stimulation policy and capital restrictions, and also traditional perspective towards housing ( i.e., Chinese are culturally inclined to keep buying a house because owning a house increases the chance of getting married ) over several decades, an increasing number of people are buying houses, and real estate development has seen a long-lasting boom. Those factors mentioned previously all contribute to the increase in housing prices in China. Although the extent of rising housing prices varies from areas to areas and from cities to villages, in general, prices are nearly double the peak that reached in the late 1990s and roughly four times higher than that in 2004 [2]. Also, Chinese home prices more broadly are rising year-over-year by around $10 \%$. In 2018, the real estate market's total sales reached almost 15 trillion yuan and accounted for nearly 17 percent of China's GDP [3].

Therefore, whether China has a housing bubble and whether this bubble, had been a quite popular topic for both economists, government administrators, and citizens, and there is no doubt that it will continue to be shed light on in the following years. The reason for these concerns is evident due to the significant losses experienced by other countries, such as the subprime crisis in 2008 and 2009. As a result, taking warning from previous financial and tangible distortion in the housing market and economy, some people are quite sensitive, and they favor the opinion that there is a housing bubble due to the ever-increasing in housing price and the very exaggerated housing Price-to-Income Ratio in China, especially in cities such as Beijing, Shanghai, Shenzhen. For example, normally, a ratio of less than $25 \%$ is reasonable, while more than $30 \%$ indicates excessive rent pressure. However, in 2018, the housing price to income ratio in the first-tier cities in China is above 50 and 30 to 40 in the third- and fourth-tier cities. [4]

In contrast, some people argue that there will not be a housing bubble, because the development of the real estate sector is determined or stimulated by several fundamental trends, making a crash of the market less likely [3]. Among those trends, the most critical aspect is the constantly advancing urbanization combined with equally increasing GDP per capita, which leads to sustained demand for new housing. In reality, in China, the rising rate of housing prices is nearly the same as the rising level of GDP per capita. It shows that the growth in income has affected all social classes, making acquiring housing property possible even for lower-income groups. Besides, a general increase in 
GDP per capita and government subsidy for people in the aspects of business and other forms of financial support makes Chinese people better off. Moreover, an increasing number of people are now more concerned with the quality of housing.

From my perspective, China has a housing bubble. Multiple evidence will be employed to support the conclusion, including a summary of previous researches done by the authoritative agency, statistics offered officials. Most parts of the explanation will be based on the reasonable condition of an economy where there is no special events or disasters.

\section{HOUSING BUBBLE'S EXISTENCE IN CHINA}

To identify whether China has a housing bubble, the very first thing to think about is what is a housing bubble and whether the current China housing market situation meets the conditions for this bubble to form.

\subsection{Housing Bubble}

This section will be divided into three parts: the definition of a housing bubble, the condition for the formation of a bubble, and the condition for the bubble to burst.

A housing bubble, or real estate bubble, is a run-up in housing prices fueled by demand, speculation, and exuberant spending to the point of collapse [5]. It is mainly caused by a shortage of housing supply, which may take specific periods, ranging from several months to several years, to happen in reality. The discordance of demand and supply is affected by a rapid increase in the supply of credit, very low-interest rates, a loosening of credit underwriting standards, and other factors, resulting in rampant speculation in the housing market, risky behavior, over-valued prices (i.e., the house does not worth that high price and an increasing number of people cannot afford that house ).

The bubble will become larger and larger until an increase of housing supply topples over decreasing demand, meaning there is no demand for the rising prices of housing in the market, and the equilibrium is broken. A drastic drop follows it in housing prices because house buyers or investors are unwilling to pay as much for the homes on the market. Meanwhile, since previously an increasing debt is borrowed by an increasing number of house buyers (the reason for such a significant amount of borrowing is that people expect the housing price to higher in the future and then they could sell the house to pay the debt), and the drastic drop makes them have more debts and a higher rate of foreclosure. A vicious cycle then is created, meaning the influx of foreclosures drives home prices even lower and further floods the market. Once the extreme risk-taking becomes too pervasive, and the supply of housing continues to increase as demand subsides, prices fall faster [6]. The adverse effects are pervasive and significant, taking a considerable amount of time to recover. The examples include the 1849 Gold Rush, the Great Depression, 2002 Crash down, 2008 Subprime crisis [7].

\subsection{Current China Housing Market}

The real estate market compose of a ket part of the Chinese economy. According to the National Bureau of Statistics of China (2018) [8], in 2017, housing sales totaled 13.37 trillion RMB, an increase of 13.7 percent, equivalent to $16.4 \%$ of China's GDP, even under a condition of targeted tightening, market differentiation, slower price growth, industry consolidation, investment slowdown [9].

Also, the real estate market and China's financial system are closely connected through several channels. Firstly, due to a lack of other investment vigils for both firms and households, capital restrictions, high risk in the stock market, and a relatively undeveloped financial market in China, housing holdings are the biggest component of Chinese households' asset portfolios [10], which means buying houses are the biggest part of Chinese investment.

Secondly, land sale revenues are heavily relied on by China's local governments. They raise revenue to pay for expenditures, such as subsidy and transfer of payment and gain the favor of Beijing through boosting their regional GDP, which will ensure them additional rewards [2], using future land sales revenues as collateral to raise debt financing through "Local Government Financing Platform” ( LGFP ) [10].

Thirdly, banks in China have a high exposure to real estate-related loans made by real estate developers, local governments, households, and firms that are either explicitly or implicitly backed by real estate assets. Through the third quarter of 2016, property-related loans totaled 55 trillion RMB, accounting for about $25 \%$ of China's banking assets. According to the Chart below, mortgage loans to households accounted for 17.9 trillion, 6.3 trillion in credit through shadow banking, loans to real estate developers accounted for 14.8 trillion including 7 trillion in regular loans, and 1.5 trillion through domestic bond issuance, and loans collateral by real estate assets to firms and local governments accounted for 22.2 trillion [10]. Bank loaning and borrowing then become a great stimulus to the housing prices in China.

\subsection{Housing Bubble in China}

China has a housing bubble. By analyzing the current situation of Chinese housing market, it is obvious to find that many parts of the market accord 
with the condition which forms a housing bubble. This part will be supported through two parts, which are households and governments including both central and local governments respectively. Both two parts stimulate the formation of the bubble and it is worth noting that some behaviors of households in the housing market is related to the behaviors of local and central governments.

\subsubsection{Households}

Chinese people are inclined to keep purchasing this new real estate.

Firstly, homeownership is, to a great extent, related to one person's marriage-worthiness and family formation. Generally, Chinese people traditionally regard owning a house as the prerequisite of getting married, because owning a house is one symbol of having a certain amount of assets and responsibilities, which ensures the steadiness of the life after marriage. Therefore, if owning a home makes a Chinese man marriageable, owning more would make him more attractive [2].

Secondly, saving is another tradition. China has one of the highest national savings rate around the world. The national savings rate has been high since 1980 s, at approximately $35 \%-40 \%$ of the national GDP. After 2001, entering into the WTO, China saves even more, surging to a peak of $52 \%$ of GDP in 2008 [11]. It is reasonable that part of the savings will be used to purchase houses as a other form of personal or household assets.

Thirdly, investment in the housing market is, to some extent, the only way that is both safe and convenient for Chinese citizens to make money. The reason behind this is that capital restrictions prevent international flight, and the stock market is much riskier than the housing market, which is both due to a less developed financial system in China, especially in the mainland. For one thing, false market demand caused by speculation raises the prices [12]. Many people, seeing the profit space in the real estate market, take a series of speculative behaviors, buy houses, and repeatedly trade them to earn a price difference. Houses are a symbol of people living and working in peace and an excellent investment product in the eyes of investors. Especially in the developed first-tier cities and second-tier cities, these phenomena are particularly noticeable. The housing price will undoubtedly show an upward trend in the next few years, which makes people more attracted to this kind of speculative behavior and leads to the increasing fake market demand. With the promulgation of China's new marriage law and the restriction on the number of houses a household could buy, people even get a nominal divorce. This fake divorce to buy a house refers to the relationship between husband and wife of one party or both parties have no real intention of divorce, to realize the common interests such as buying a house, through the two parties conspired or by the other party fraud and marriage registration authorities to apply for a dishonest act of divorce registration. For example, a Chinese couple from Shanghai, Mr and Mrs Cai, decided to make a fake divorce to buy an apartment for 3.6 million yuan (US\$532,583), because of the limitation of Chinese government of purchasing properties [13].

The evidence that most Chinese buy a house for investment, but not for domicile, is that most homes sold now stay vacant and unfurnished. According to Chinese Furniture Sales in June 2016 to June 2019 [2], Chinese furniture sales are down 14\% from June 2018 to June 2019. This can be seen from Figure 1.

Also, although Chinese people are traditionally savers, the trend now goes with time. Recently, borrowing from the bank is increasing, which is support by the chart Figure3. The high passion for buying a house stimulus the demand for houses in China, contributing to the ever-increasing housing prices in China. 


\section{Chinese Furniture Sales (June 2016 - June 2019)}

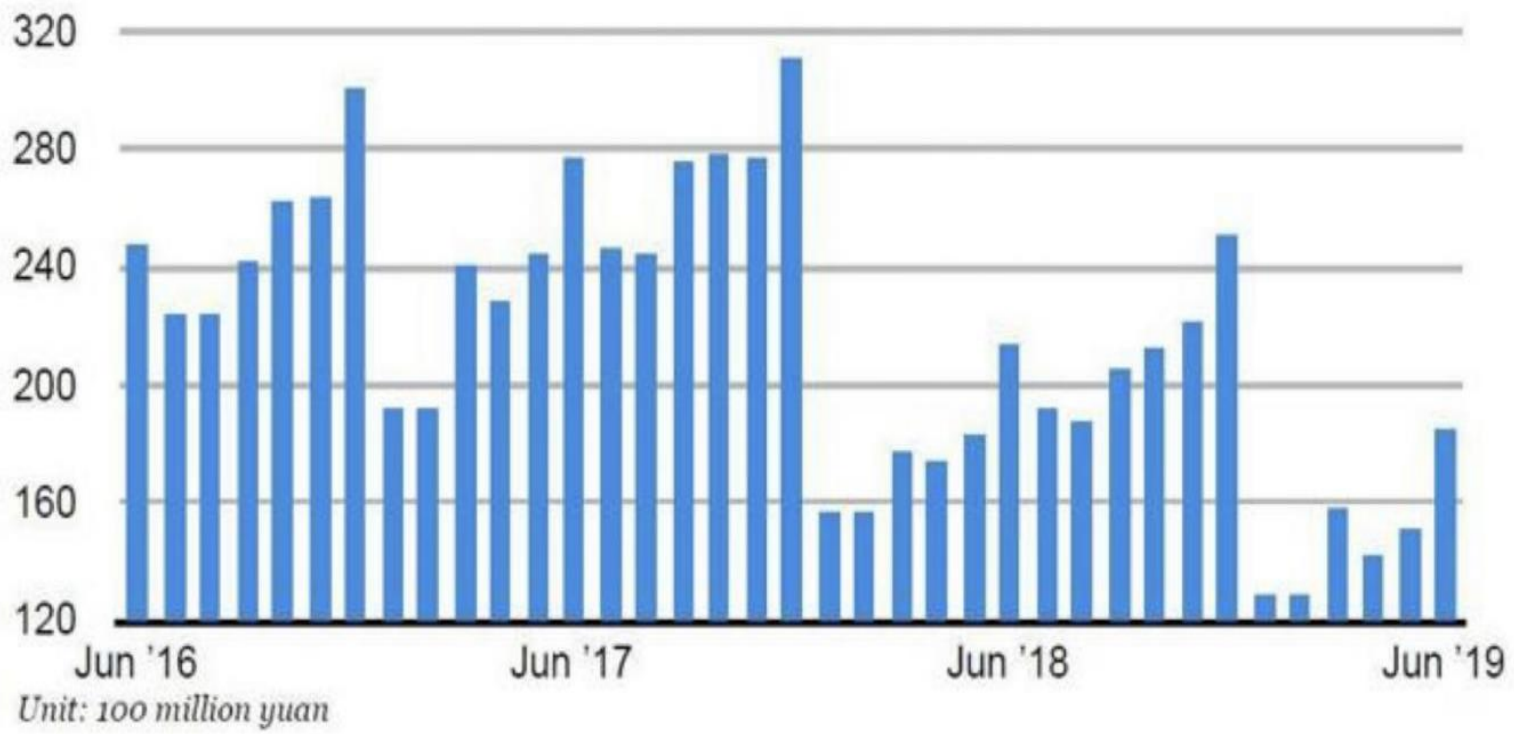

Figure 1 Chinese Furniture Sales (June 2016 -June 2019) [2]

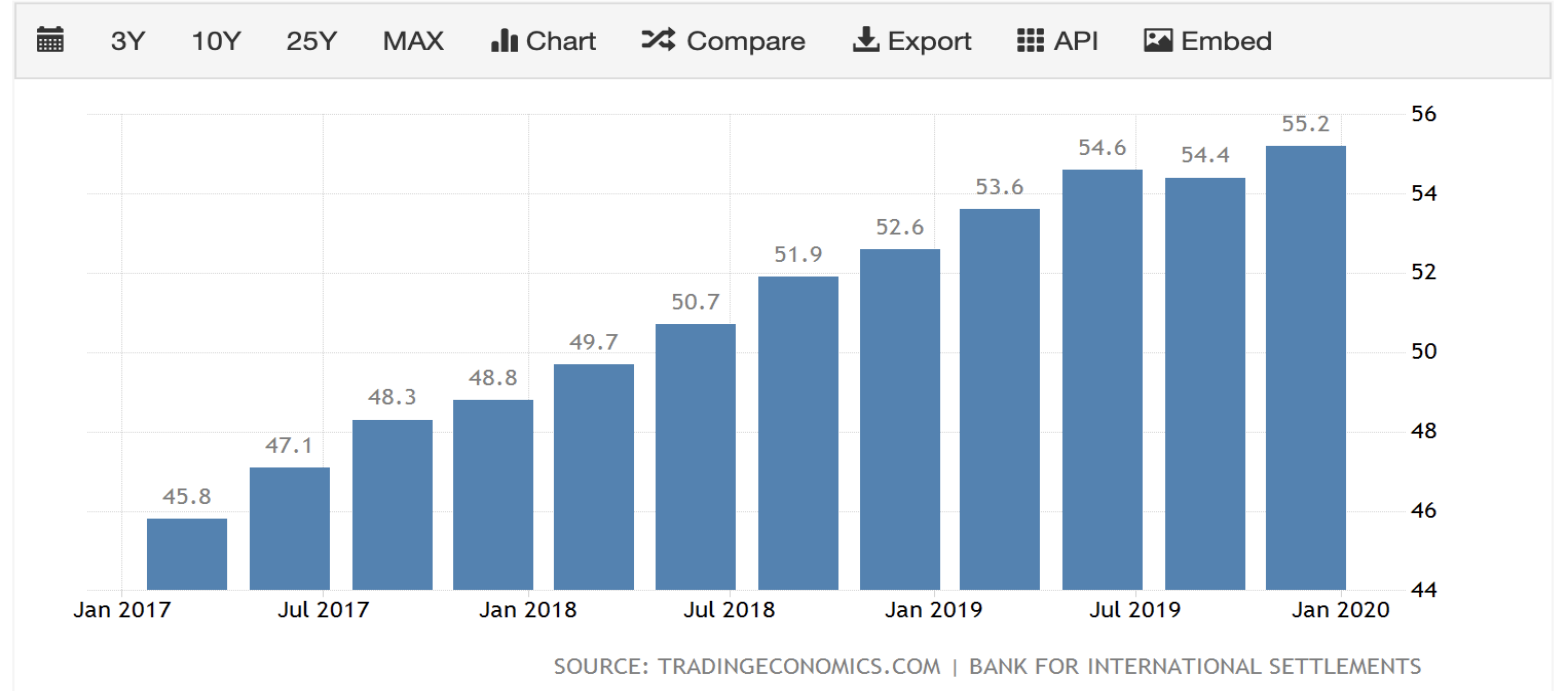

\begin{tabular}{|llllllll|}
\hline Actual & Previous & Highest & Lowest & Dates & Unit & Frequency \\
\hline 55.20 & 54.40 & 55.20 & 10.80 & $2006-2019$ & percent of GDP & Quarterly & NSA \\
\hline
\end{tabular}

Figure 2 China Households Debt To GDP [14]

\subsubsection{Governments (local and central)}

Firstly, the land resource in China is scarce. Since the implementation of the tax distribution reform in 1994, a majority of local fiscal revenue is handed over to the state, with local governments retaining only a small share of the revenue. According to China Statistical Yearbook, 1994 [15], the proportion of China's local fiscal revenue to the country's budgetary revenue decreased drastically from $77.98 \%$ in 1993 yo
$44.3 \%$ in 1994 , whereas the proportion of transaction expenditure dropped by $2 \%$ from $71.74 \%$ to $69.72 \%$. To solve the problem of insufficient local fiscal revenue and to support urban economic construction, and with the monopoly of land resources, local governments become increasingly dependent on land finance, which means the transfers of land ownership [16]. For example, the ratio of the local government's financial expenditures to fiscal revenue soared from $5.7 \%$ in 1997 to $23.4 \%$ in 2015 , showing a massive increase in the 
dependence of land resources by local governments [17]. This creates a shortage of land, resulting in higher prices for land resources. The land buyers then need to sell at an even higher price to compensate for the losses, creating burdens for the Chinese consumers.

Secondly, government stimulus plans also play a part in driving the house prices and the formation of housing bubbles. Local GDP growth is one of the main goals of local governments. To achieve this goal, local governments should stimulate the growth in a short period. They made this by the promotion championship incentive system. Because of the huge profits behind the housing market, they become the target and win the support from local governments [16].
Thirdly, the loosening of currency policy by the central bank also plays a part. Although it helps increase the aggregate demand by making borrowing easier and helps the economy go through the crisis, it creates a surplus of production in Chinese society. The growth rate of M2 from 2009 to 2015 was much higher than the GDP growth rate, indicating that investment intensified in the Chinese market during this period [16]. When the money supply is much higher than the GDP growth rate, there will be extra money to invest, and real estate is an essential area of capital inflow. The high growth rate of money issuance from 2009 to 2015 resulted in a high growth rate of money flowing into real estate, which led to the aggravation of the real estate bubble during this period.

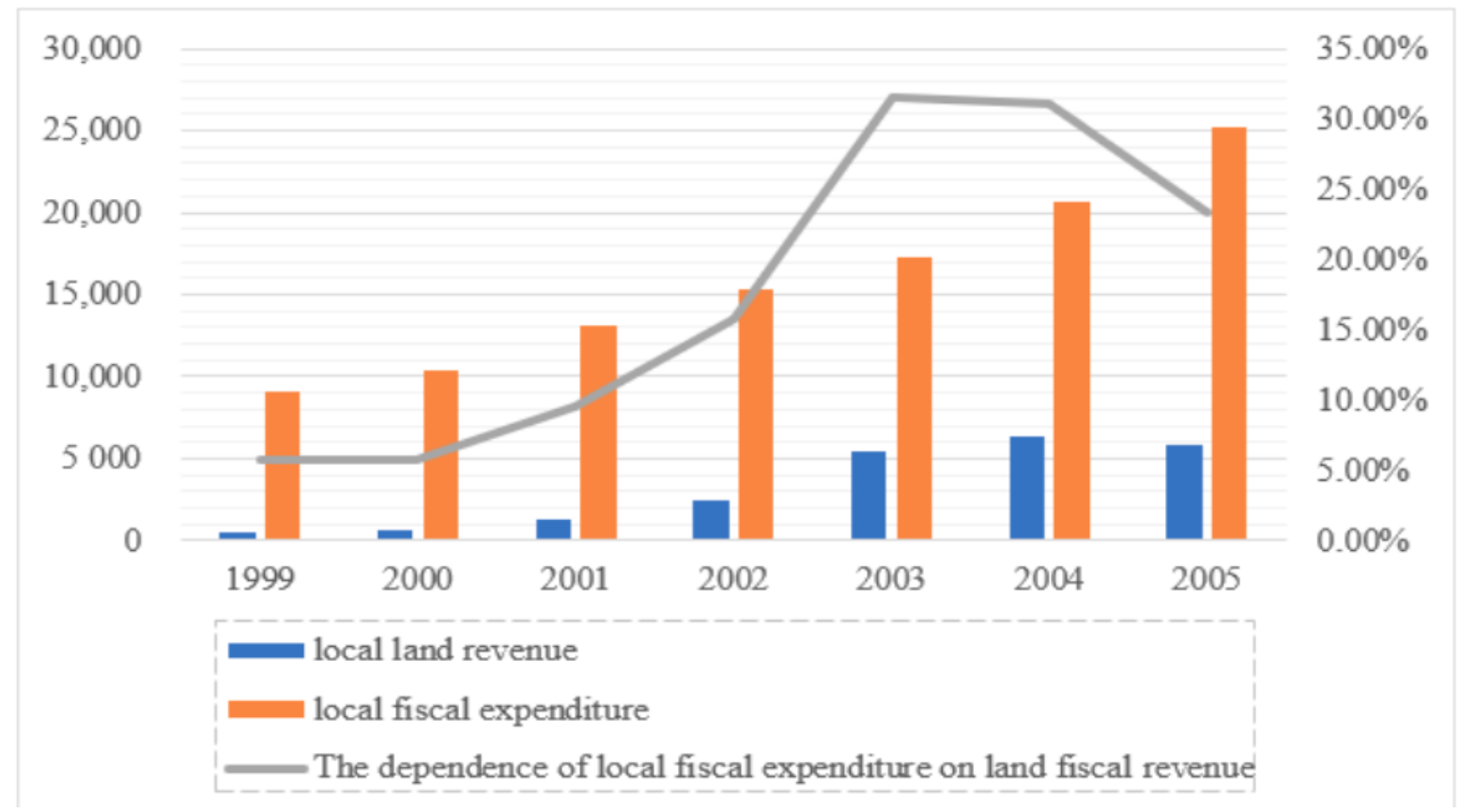

Figure 3 China's land finance income and expenditure and the correlation (1999-2015) [17]

\section{CONCLUSION}

To sum up, China has a housing bubble. Due to the severe problems caused by the burst of this bubble, governments should implement developed plans to decrease the growth of the housing bubble and avoid the burst of the bubble. Also plans aimed to help the economy recovered from the burst of bubble should also be prepared.

\section{ACKNOWLEDGMENT}

In the writing process of this paper, from the topic selection of this paper, to the guidance of paper thinking, text organization, structure arrangement and arrangement, and then to the modification of the paper, from beginning to end, I have been carefully guided by the teacher. Because of the teacher's rigorous scholarship and a lot of painstaking effort, I successfully completed the writing of this article. Once again, I sincerely thank the teacher for his guidance!

\section{REFERENCES}

[1] James Chen 2019, Real Estate, viewed 31, July 2020. https://www.investopedia.com/terms/r/realestate.as $\mathrm{p}$

[2] Cashflow Capitalist 2019, The Chinese Real Estate Bubble Conundrum: The problem And the Wrong Solution, viewed 31 July 2020. https://seekingalpha.com/article/4276761-chinese-r eal-estate-bubble-conundrum-problem-and-wrongsolution

[3] C.Textor 2020, Real estate in China - statistics \& facts, viewed July $31 \quad 2020$ 
https://www.statista.com/topics/1500/real-estate-inchina/

[4] Yi Xianrong 2018, the School of Economics at Qingdao University, Housing costs key constraint to Chinese consumption, viewed 1 August 2020. https://www.globaltimes.cn/content/1121946.shtml

[5] Jim Chappelow 2019, housing bubble, viewed 1 August 2020. https://www.investopedia.com/terms/h/housing_bu bble.asp

[6] Liz Smith 2018, What Is a Housing Bubble, viewed 1 August 2020.

https://smartasset.com/mortgage/what-is-a-housing -bubble

[7] UpNest, Housing Bubble — What It Is And Historical Examples, viewed 2 August 2020. https://www.upnest.com/1/post/housing-bubble-wh at-it-is-and-historical-examples/

[8] National Bureau of Statistics of China 2018, National Real Estate Development and Sales in 2017, viewed 2 August 2020, http://www.stats.gov.cn/english/PressRelease/2018 01/t20180126_1577671.html

[9] Spencer Sheehan. Trends in Chinese Real Estate Market in 2017, The Diplomat. viewed 2 August 2020,

https://thediplomat.com/2017/02/5-trends-in-chinas -real-estate-market-in-2017/

[10] Chang Liu. and Wei Xiong 2018, CHINA'S REAL ESTATE MARKET, the National Bureau of Economic Research, Princeton University, viewed 3 August 2020, https://www.nber.org/papers/w25297

[11] Longmei Zhang, Ray Brooks, Ding Ding, Haiyan Ding, Hui He, Jing Lu, and Rui Mano 2018, Chinese High Savings: Drivers, Prospects and Policies, Asia Pacific Department, viewed 12, August 2020, IMF Working Paper WP/18/277

[12] Ma Lili 2018, Reflections on The Real Estate Economic Bubble in China [J], Urban Construction Theory Research (Electronic Version), 2018(14):163, pp. 163, viewed 12 August 2020, http://kns.cnki.net/kcms/detail/detail.aspx?FileNam

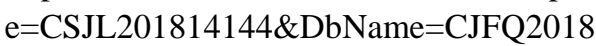

[13] Bloomberg 2016, Fake divorce one route to riches as Chinese cities impose housing restrictions to tackle property bubble, viewed 12 August 2020, https://www.scmp.com/news/china/economy/articl e/2039498/fake-divorce-one-route-riches-chinese-c ities-impose-housing
[14] Trading Economics, China Households Debt To GDP, viewed 12 August 2020, https://tradingeconomics.com/china/households-de bt-to-gdp

[15] Xin, B.; Yu, S. A probe into the correlation between land finance and local economic growth. Contemp. Finan. Econ. 2010, 43-47, viewed 12 August 2020

[16] Chen Shi Nuo, National circulation economy. Issue 03, 2020, pp. 120-121, viewed 12 August. 2020,https://navi.cnki.net/KNavi/JournalDetail?pco $\mathrm{de}=\mathrm{CJFD} \&$ pykm $=\mathrm{QGSQ} \&$ Year $=\&$ Issue $=$

[17] Xinhua Zhu, Yigang Wei, Yani Lai, Yan Li, Sujuan Zhong and Chun Dai 2018, Empirical Analysis of the Driving Factors of Chinese 'Land Finance' Mechanism Using Soft Budget Constraint Theory and the PLS-SEM Model, Sustainability 2019, 11, 742. doi:10.3390/su11030742, viewed 12 August 2020 , https://www.mdpi.com/journal/sustainability 